\title{
Toward an Understanding of Peer Influence on Undergraduate Study Abroad Participation
}

\section{Melissa Whatley}

University of Georgia

\begin{abstract}
:
This study explores the role of peer influence on students' decisions to participate in study abroad. Although previous research has identified many factors that relate to study abroad participation, peer influence represents an underexplored factor for consideration in this line of research. Using the tools of social network analysis, this study finds a small but significant relationship between peer study abroad and a student's participation in study abroad. Results provide food for thought about the way peers may influence students in their decisions surrounding study abroad, both directly and indirectly. This line of inquiry has important implications for education abroad professionals who seek to leverage peer influence so that students make optimal decisions about study abroad.
\end{abstract}

\section{Introduction}

The Open Doors Report, released annually by the Institute of International Education, consistently indicates that the number of U.S. undergraduate students participating in study abroad is increasing. For example, during the 2015-16 academic year, the latest year for which data are available, over 300,000 U.S. students studied abroad, representing an increase of approximately 3\% over the prior academic year (Institute of International Education, 2017). This increase in study abroad participation has been accompanied by a growing awareness on the part of policy-and decision-makers at all levels, from individual institutions of higher education to the federal government, that international experiences are essential to the development of the skills that students need to compete in a global economy. Indeed, skills such as foreign language ability and intercultural competence may be best acquired in the world beyond U.S. borders (Engle \& Engle, 2004; Freed, 1995; Lokkesmoe, Kuchinke, \& Ardichvili, 2016; Regan, Howard, \& Lemée, 2009; Williams, 2005). The spirit of these calls for increases in the number of students who participate in study abroad are exemplified by federal initiatives, such as the introduction of the Senator Paul Simon Study Abroad Program Act in 2017 and the establishment of the 100,000 Strong in the Americas Innovation Fund in 2014. The first of these initiatives, the Simon Act, seeks to establish funding for competitive grants to institutions of higher education in pursuit of three main goals: 1) send one million U.S. students abroad per academic year for credit; 2) establish demographic representativeness among the population of students who study abroad (e.g., in terms of race/ethnicity, gender); and 3) encourage study abroad participation in nontraditional (i.e., nonEuropean) destinations (NAFSA, 2017). Similarly, the 100,000 Strong in the Americas Innovation Fund represents a public-private sector collaboration established by the Obama administration that provides grant funding to institutions of higher education in the western hemisphere. This initiative has the goal of increasing student exchange and educational opportunity across the Americas

Frontiers: The Interdisciplinary Journal of Study Abroad, Vol. XXX, Issue 3, (November 2018): pp. 51-71. 
(100,000 Strong in the Americas, 2017). To date, over 90 grants have been awarded, and additional grant competitions continue to be announced.

Researchers have answered calls for increases in the number of students who participate in study abroad with investigations that explore factors that may relate to whether a student chooses to study abroad over the course of his or her academic career. The work of Salisbury and colleagues $(2009,2010,2011)$ is representative of this strand of research, and indicates that students who study abroad tend to be white and female, and come from higher socioeconomic status groups. Indeed, researchers have found that students face a variety of barriers to study abroad, such as lack of affordability, paucity of programs within certain fields of study, and incomplete information about international opportunities (e.g., Brux \& Fry, 2010; Dessoff, 2006; Doyle, Gendall, Meyer, Hoek, Tait, McKenzie, \& Loorparg, 2010; Luo \& Jamieson-Drake, 2015; McClure, Szélenyi, Niehaus, Anderson, \& Reed, 2010; Niehaus \& Inkelas, 2016; Salisbury, Paulsen, \& Pascarella, 2010, 2011; Salisbury, Umbach, Paulsen, \& Pascarella, 2009; Stroud, 2010; Van Der Meid, 2003). Although such research has increased our understanding of who participates in study abroad in terms of individual student characteristics, and informs decision-making concerning policies and practices that may increase study abroad participation, considerably less attention has been paid in the literature to the role that a student's peers may play in his or her decision to participate in study abroad. At the same time, researchers have recommended the use of students' peer networks in the promotion and encouragement of study abroad participation (e.g., Goldstein \& Kim, 2006; Lo, 2006). The current study seeks to fill this gap in our knowledge by using the tools of social network analysis to quantify peer influence and explore its role in a student's study abroad decision-making.

\section{Relevant Literature}

As mentioned in the introductory remarks, researchers have established a robust body of literature using multiple methods of inquiry that provides a foundation for understanding who participates in study abroad. These studies consistently indicate that study abroad students are not necessarily representative of the U.S. undergraduate student body in that they tend to be white, female, and come from high socioeconomic status households with higher levels of parental educational attainment (e.g., Dessoff, 2006; Luo \& Jamieson-Drake, 2015; Salisbury et al., 2010, 2011; Salisbury et al., 2009; Stroud, 2010; Whatley, 2017). Researchers have additionally found that student attitudinal and behavioral traits influence their participation in study abroad. For example, Goldstein and Kim (2006) find that expectations of study abroad play a critical role in a student's subsequent study abroad participation and that students who exhibit high levels of ethnocentrism and prejudice are considerably less likely to study abroad. Along these same lines, Luo and JamiesonDrake (2015) uncover evidence that intent to participate in certain student groups, such as fraternity or sorority organizations or other student clubs centered around common interests, is significantly associated with an increased intent to study abroad.

As Salisbury et al. (2009) indicate, the decision to study abroad appears to be influenced by a complex interplay of factors associated with students' backgrounds and socioeconomic status, and additional forms of cultural and social capital that they acquire both prior to and during their university-level studies. The current study expands on this prior research by focusing on a factor in students' study abroad decision-making that has been underexplored in the literature - the role of students' social network peers. 


\section{Peer Influence in College}

Although prior investigation concerning peer influence on students' study abroad patterns remains thin, researchers have documented the role that peer networks play in other decisions that students make in higher education. This body of literature documents a role for peers in students' choices concerning a variety of higher education decisions, ranging from those surrounding college attendance and persistence (e.g., Arbona \& Nora, 2007; Thomas, 2000) to decisions to engage in certain behaviors while in college, such as drinking (Borsari \& Carey, 2001) and academic cheating (McCabe, Treviño, \& Butterfield, 2001). In a study that employed an analysis technique that is very similar to that of the current study, González Canché and Rios-Aguilar (2015) found evidence that community college students who were surrounded by peers taking a greater number of credit hours were more likely to take more credit hours themselves. Moreover, these researchers provide evidence that this peer effect on credit hour enrollment was more pronounced among African American and Latino males. In other words, African American and Latino males who interacted with African American and Latino male classmates with higher-credit-hour loads took a significantly higher number of credit hours themselves. Results of studies such as this one shed new light on theories that posit a substantial role for student involvement and engagement with their peers in student success (e.g., Astin, 1984; Pascarella, 1985; Tinto, 1987).

\section{Peer Influence on Study Abroad}

Although no study to date within the study abroad literature has focused extensively on peer influence, previous research does provide some evidence that suggests a role for a student's peers in the decision to study abroad. Two studies, Zhai and Scheer (2002) and Kasravi (2009), offer descriptive statistics concerning a potential peer effect on student participation in study abroad. Specifically, Zhai and Scheer (2002) found that 33\% of the students that they interviewed indicated that knowing students who had previously participated in study abroad positively influenced their own decisions to study abroad. Kasravi (2009) similarly found that $61.3 \%$ of participants, representing ethnic minority groups, indicated that former study abroad participants were influential in their decisions about study abroad.

Luo and Jamieson-Drake (2015) offer additional evidence for a possible peer effect on students' study abroad participation. These authors found that high school students who expected to join fraternities, sororities, or other student groups in college were more likely to intend to participate in study abroad. Additionally, their findings indicated that high school students who spent time socializing with friends were more likely to intend to study abroad. These results suggest that students who plan to be more active in campus life, and who intend to surround themselves with peers from their institutional environments, are more likely to study internationally. Along these same lines, Salisbury et al. (2009) found that students with higher levels of co-curricular involvement were significantly more likely to intend to participate in study abroad. This same study (Salisbury et al., 2009) included a variable for peer interactions, measured using a seven-item scale containing Likert-type response items such as "I have developed close personal relationships with other students," that was used to predict first-year students' intent to study abroad. While this variable did not reach statistical significance among students in general (Salisbury et al., 2009), or among students when divided by gender (Salisbury et al., 2010) or ethnicity (Salisbury et al., 2011), Salisbury et al. (2010) found that the effect of this variable accounted for a significant difference between male and 
female students. Specifically, an increase on this peer interaction scale was associated with a decrease in the likelihood of intent to participate in study abroad among male students but an increase in its likelihood among female students.

Taken together, these studies offer a complicated, and possibly incomplete, picture of how a student's peers relate to his or her participation in study abroad. Indeed, some studies have found a negative or insignificant effect for peer influence (Salisbury et al., 2010, 2011; Salisbury et al., 2009) while others report a seemingly positive influence of peers, especially when considering student involvement, on students' participation in study abroad (Kasravi, 2009; Luo \& Jamieson-Drake, 2015; Salisbury et al., 2009; Zhai \& Scheer, 2002). Findings such as those of the latter group are likely what lead researchers to recommend the use of students' peers to change their expectations of study abroad (Goldstein \& Kim, 2006) or to aid students in the study abroad decision-making process as peer advisors (Lo, 2006). However, the study abroad office representatives participating in Williams' (2007) study indicated that peer influence may negatively influence study abroad participation among minority students. It is clear that the role of students' peers in the study abroad decision-making process remains a poorly understood construct in the literature. Unlike previous research, which examines peer influence in the context of many other factors that likely encourage student participation in study abroad, the current study places possible peer effects at the forefront of inquiry and serves as a step toward a deeper understanding of the role that a student's peers play in his or her decision-making about international experiences.

\section{Theoretical Framework}

Like other research that has examined students' study abroad participation patterns (Fornerino, Jolibert, Sánchez, \& Zhang, 2011; Goel, de Jong \& Schnusenberg, 2010; Presley, Damron-Martinez, \& Zhang, 2010; Schnusenberg, de Jong, \& Goel, 2012), this study is guided by Ajzen and Fishbein's theory of planned behavior (Ajzen, 1988, 1991; Ajzen \& Fishbein, 1980, 2005; Fishbein \& Ajzen, 1975). This theoretical approach conceptualizes observed human behavior as the result of an intent to engage in such behavior. In the context of study abroad, the theory of planned behavior suggests that a student's participation in study abroad is an overt manifestation of an intent to study abroad. Ajzen (1988, 1991), Ajzen and Fishbein (1980, 2005), and Fishbein and Ajzen (1975) develop three independent constructs that influence human intention before it is translated into overt behavior: attitude toward behavior, perceived behavioral control, and subjective norms.

Attitude toward behavior refers to the degree to which a person holds positive or negative beliefs about a given behavior. Study abroad, for example, may be viewed as a career-enhancing experience by one student and a distraction to timely degree completion by another. Perceived behavioral control, on the other hand, refers to one's perception of how much control one has over participation in a certain behavior. This construct deals with beliefs about the presence or absence of the required resources and opportunities for such behavior. These beliefs may be the result of past experiences, but may also reflect secondhand information garnered from a variety of sources, such as parents and teachers. For example, students within certain fields of study may view study abroad as incongruous with their academic trajectories, even if such opportunities do exist. This perspective may be enhanced if professors from a student's field of study do not explicitly mention or encourage study abroad participation. Finally, subjective norms correspond to the social pressure that a person feels to participate in certain experiences, and are linked to beliefs about approval or 
disapproval of individuals or groups regarding such participation. This last concept is the focus of the current study, and is operationalized as peer influence on the decision to study abroad.

\section{The Current Study}

The overarching goal of the current study is to apply the tools of social network analysis to achieve a better understanding of the role of peer influence in students' study abroad decisionmaking. More specifically, this study seeks answers to the following three research questions:

1. Is there evidence suggestive of peer influence on students' participation in study abroad?

2. Is there evidence suggestive of peer influence on students' intent to participate in study abroad?

3. Is there evidence suggestive of peer influence on students' positive disposition toward study abroad, defined as either actual participation in or intent to participate in study abroad?

The following section discusses the method employed to measure peer effects and to provide answers to these three research questions.

\section{Method}

\section{Data}

This study employs Greek organizations (fraternities and sororities) at a large public research university to delineate a student's peer group. The use of such organizations to define who is and who is not a student's peer is advantageous as these organizations have clear boundaries - one is either a member of a given fraternity or sorority, or not. Although members of these organizations are certainly in contact with students outside of their fraternal associations, this study assumes that students who are members of the same Greek organization by default spend a considerable portion of their time together through meetings, official organization-sponsored activities, and social gatherings. This time together is expected to result in a certain amount of influence on each other's actions and decisions, specifically concerning study abroad.

Data about students' study abroad patterns and decisions, as well as information about other student characteristics shown by previous research to influence undergraduates' study abroad patterns, were collected using an electronic survey during the 2016-17 academic year. This survey was distributed to all members of Greek organizations through official university listservs and through the leaders of Greek organizations at the beginning of each semester. In total, 57 students representing eleven Greek organizations completed the survey. Of these 57 responses, four were omitted from analyses as they represented the only students in their organizations to participate in the survey and, given the lack of data on these students' peers, no measure of peer influence could be calculated. As such, the analyses presented herein explore the study abroad behaviors and plans of 53 students belonging to seven organizations. ${ }^{1}$

The subset of survey questions employed for this study (see Appendix A) asked students to report on their study abroad participation and plans, and collected additional data on student

\footnotetext{
${ }^{1}$ Greek organizations were given pseudonyms to protect the identities of participants.
} 
characteristics. Concerning education abroad, the survey asked students to report whether they had participated in a study abroad program while in college. If a student responded no to this survey item, he or she was then asked whether he or she intended to study abroad while at college. A general measure of positive disposition toward study abroad was derived from these two survey items to enable comparison between students who were open to the idea of study abroad with those who did not even consider study abroad as a possible future event. It was determined that if a student had either participated in or planned to participate in study abroad, then he or she was positively disposed toward study abroad. This variable has the additional advantage of controlling for the effect that a student's year of university study may have on his or her realized study abroad participation. That is, a student who was in the first year of university studies may have simply not yet had enough time to study abroad.

Other student characteristics collected in this survey included gender, race/ethnicity, age, current GPA, major, and whether a student had traveled abroad before. Of these characteristics, race/ethnicity and age were not included in the final analyses of this study due to a lack of variation. Specifically, only two students selected race/ethnicity groups that were not White/Caucasian, and all students were between 18 and 22 years old with an average age of 19.85 (SD=1.18). Student majors were initially classified according to their CIP code, a standardized classification defined by the National Center for Education Statistics (NCES, 2010). If a student listed more than one major, the first major listed was used for classification purposes. Several major categories were subsequently collapsed into a category labeled "Other" due to low representativeness in the dataset. These categories included majors in Journalism/Communications and Fine Arts/Humanities, and a single student whose major was Undecided. As such, the field of study categories retained for analyses were: Science, Technology, Engineering, and Mathematics (STEM); Social Sciences; Business; and Other.

\section{Peer Effect Measure}

A measure of peer effect, based on whether the other members of a given student's Greek organization had participated in study abroad, was created for each student using social network analysis tools. This measure follows Valente (2005) in calculating a measure of personal network exposure $\left(E_{i}\right)$ to study abroad for each student. The formal equation for this measure is as follows:

$$
E_{i}=\frac{\sum w_{i j} y_{j}}{\sum w_{i}}
$$

wherein $w_{i j}$ corresponds to a social network weight matrix for student in Greek organization $_{j}, y_{j}$ is a vector of adoptions (in this case, study abroad participation) for organization, and $w_{i}$ is a weight

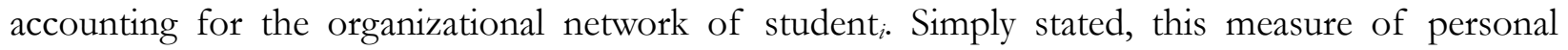
network exposure represents the proportion of members of a student's Greek organization, aside from that student. who participated in study abroad.

In practice, this measure of personal network exposure was calculated using matrix algebra and manipulation. The details of this calculation appear in Appendix B. In brief, data concerning students' Greek organizational affiliations informed the creation of a peer-to-peer network matrix, illustrated in Figure 1. In this matrix, a 1 indicates that two students, represented by the student 
numbers at the heads of rows and columns, were members of the same Greek organization, while a 0 indicates that they were not members of the same organization. For example, the 1 in the second column of the first row indicates that students 1 and 2 were in the same Greek organization. The 0 in the fourth column of the first row indicates that students 1 and 4 were not in the same organization. So that a student was not counted as a member of his or her own peer group (i.e., so that a student's peer group consisted of all members of his or her Greek organization besides him or herself), the diagonal of this matrix was converted to 0 .

Figure 1. Peer-to-peer Greek organization network of students without self-selection

$\left[\begin{array}{ccccccccccccc}\text { Student } & 1 & 2 & 3 & 4 & 5 & 6 & 7 & 8 & 9 & 10 & 11 & N \\ 1 & 0 & 1 & 1 & 0 & 0 & 0 & 0 & 0 & 0 & 0 & 0 & \cdots \\ 2 & 1 & 0 & 1 & 0 & 0 & 0 & 0 & 0 & 0 & 0 & 0 & \cdots \\ 3 & 1 & 1 & 0 & 0 & 0 & 0 & 0 & 0 & 0 & 0 & 0 & \cdots \\ 4 & 0 & 0 & 0 & 0 & 1 & 1 & 0 & 0 & 0 & 0 & 0 & \cdots \\ 5 & 0 & 0 & 0 & 1 & 0 & 1 & 0 & 0 & 0 & 0 & 0 & \cdots \\ 6 & 0 & 0 & 0 & 1 & 1 & 0 & 0 & 0 & 0 & 0 & 0 & \cdots \\ 7 & 0 & 0 & 0 & 0 & 0 & 0 & 0 & 1 & 1 & 1 & 1 & \cdots \\ 8 & 0 & 0 & 0 & 0 & 0 & 0 & 1 & 0 & 1 & 1 & 1 & \cdots \\ 9 & 0 & 0 & 0 & 0 & 0 & 0 & 1 & 1 & 0 & 1 & 1 & \cdots \\ 10 & 0 & 0 & 0 & 0 & 0 & 0 & 1 & 1 & 1 & 0 & 1 & \cdots \\ 11 & 0 & 0 & 0 & 0 & 0 & 0 & 1 & 1 & 1 & 1 & 0 & \cdots \\ N & \cdots & \cdots & \cdots & \cdots & \cdots & \cdots & \cdots & \cdots & \cdots & \cdots & \cdots & \cdots\end{array}\right]$

Similarly, a peer-to-peer study abroad matrix was extracted from the data. In this matrix, row entries represent a peer's participation in study abroad status, as illustrated in Figure 2. Specifically, a 1 appears in a column for a given student's row if two conditions are met: 1) the student represented in the column belonged to the same Greek organization as the row student (i.e., was a peer of the student) and 2) the student represented in the column participated in study abroad. For example, student 2 is both a peer of student 1 and studied abroad. These relationships are captured by a 1 in the first row (student 1) of the second column (student 2). Note that the diagonal of this matrix, like that of the matrix of the peer-to-peer network based on Greek organization in Figure 1, is set equal to 0 so that a student is not counted among his or her study abroad peer group. 
Figure 2. Peer-to-peer study abroad network

$$
\left[\begin{array}{ccccccccccccc}
\text { Student } & 1 & 2 & 3 & 4 & 5 & 6 & 7 & 8 & 9 & 10 & 11 & N \\
1 & 0 & 1 & 0 & 0 & 0 & 0 & 0 & 0 & 0 & 0 & 0 & \cdots \\
2 & 0 & 0 & 0 & 0 & 0 & 0 & 0 & 0 & 0 & 0 & 0 & \cdots \\
3 & 0 & 1 & 0 & 0 & 0 & 0 & 0 & 0 & 0 & 0 & 0 & \cdots \\
4 & 0 & 0 & 0 & 0 & 1 & 0 & 0 & 0 & 0 & 0 & 0 & \cdots \\
5 & 0 & 0 & 0 & 0 & 0 & 0 & 0 & 0 & 0 & 0 & 0 & \cdots \\
6 & 0 & 0 & 0 & 0 & 1 & 0 & 0 & 0 & 0 & 0 & 0 & \cdots \\
7 & 0 & 0 & 0 & 0 & 0 & 0 & 0 & 0 & 0 & 0 & 0 & \cdots \\
8 & 0 & 0 & 0 & 0 & 0 & 0 & 0 & 0 & 0 & 0 & 0 & \cdots \\
9 & 0 & 0 & 0 & 0 & 0 & 0 & 0 & 0 & 0 & 0 & 0 & \cdots \\
10 & 0 & 0 & 0 & 0 & 0 & 0 & 0 & 0 & 0 & 0 & 0 & \cdots \\
11 & 0 & 0 & 0 & 0 & 0 & 0 & 0 & 0 & 0 & 0 & 0 & \cdots \\
N & \cdots & \cdots & \cdots & \cdots & \cdots & \cdots & \cdots & \cdots & \cdots & \cdots & \cdots & \cdots
\end{array}\right]
$$

The peer-to-peer networks represented in Figures 1 (Greek organization) and 2 (study abroad) were subsequently used to calculate the measure of personal network exposure to study abroad represented in equation 1 . Specifically, row sums for both matrices were calculated for each student. The row sums resulting from the peer-to-peer Greek organization matrix in Figure 1 calculated the number of peers a student had in his or her Greek organization while the row sums resulting from the peer-to-peer study abroad matrix in Figure 2 calculated the number of peers with study abroad experience. The proportion of a student's peers with study abroad experience was then calculated by dividing the number of peers with study abroad experience by the total number of peers for each student. Figure 3 provides examples of how these measures were calculated for students in two example Greek organizations, Alpha Pi Omega (students 1-3) and Beta Sigma Chi (students 4-6).

Figure 3. Example peer influence measures

$$
\left[\begin{array}{cccc}
\text { Student } & \text { \#peersSA } & \text { \#peers } & \text { \#peersSA } \\
\cline { 4 - 4 } 1 & 1 & 2 & \text { \#peers } \\
2 & 0 & 2 & 0.5 \\
3 & 1 & 2 & 0 \\
4 & 1 & 2 & 0.5 \\
5 & 0 & 2 & 0 \\
6 & 1 & 2 & 0.5 \\
N & \cdots & \cdots & \cdots / \cdots
\end{array}\right]
$$

The peer effects measure found in the last column of Figure 3 was then extracted and merged with the dataset containing all other student information, namely study abroad participation, intent to participate in study abroad, disposition toward study abroad, GPA, gender, previous abroad experience, and major.

\section{Analysis}

Since the three study abroad outcomes explored in this investigation are all binary measures (e.g., a student either participated in study abroad or did not), logistic regression was employed to 
test the relationship between the peer effect variable and students' study abroad decisions. One regression analysis was conducted for each of the three outcome variables of interest. These regressions are represented in equation 2:

$$
\ln \left(\frac{p}{1-p}\right)=\alpha+P \operatorname{eer} \beta+\gamma C,
$$

wherein the outcome is study abroad participation, intent to study abroad, or positive disposition toward study abroad; Peer represents the measure of personal network exposure to study abroad (as just explained); and $C$ is a matrix of student-level control variables, namely current GPA, gender, whether a student had previous abroad experience, and major. ${ }^{2}$

\section{Results}

\section{Descriptive Statistics}

The descriptive statistics in Table 1 provide a general picture of the students who participated in this study. Specifically, 32\% (N=17) of students had already studied abroad, 61\% (N=22) of students who had not studied abroad $(\mathrm{N}=36)$ intended to do so at some point during their studies, and $74 \%(\mathrm{~N}=39)$ of all students held a positive disposition toward study abroad, ${ }^{3}$ as evidenced by either participation in or intent to participate in study abroad. The sociogram in Figure 4 depicts peer groups graphically. In this figure, students are connected according to their Greek organizational affiliation. Students with study abroad experience are shown in pink while those without are shown in green.

Concerning students' personal network exposure to study abroad, the peer effects measure indicated that on average, $46 \%$ of peers had studied abroad. As for control variables, female students comprised $47 \%$ of the dataset and $70 \%$ of participants had traveled abroad before. The average current GPA of students was 3.59 (on a four-point scale). In terms of major, $40 \%$ of students were studying a field related to Business, $26 \%$ were majoring in a STEM field, $21 \%$ were Social Science majors, and 13\% of students listed majors falling into the "Other" category.

\footnotetext{
${ }^{2}$ Exploratory models that controlled for the interaction of these control variables with the peer influence measure were also calculated, however none of these interactions returned significant results. As such, these models are not presented in this paper but are available upon request.

${ }^{3}$ The reader is reminded that a general measure of positive disposition toward study abroad was derived from measures for study abroad participation and intent to study abroad. For more details see the "Data" subsection.
} 
Melissa Whatley

Figure 4. Study abroad patterns in Greek organizations

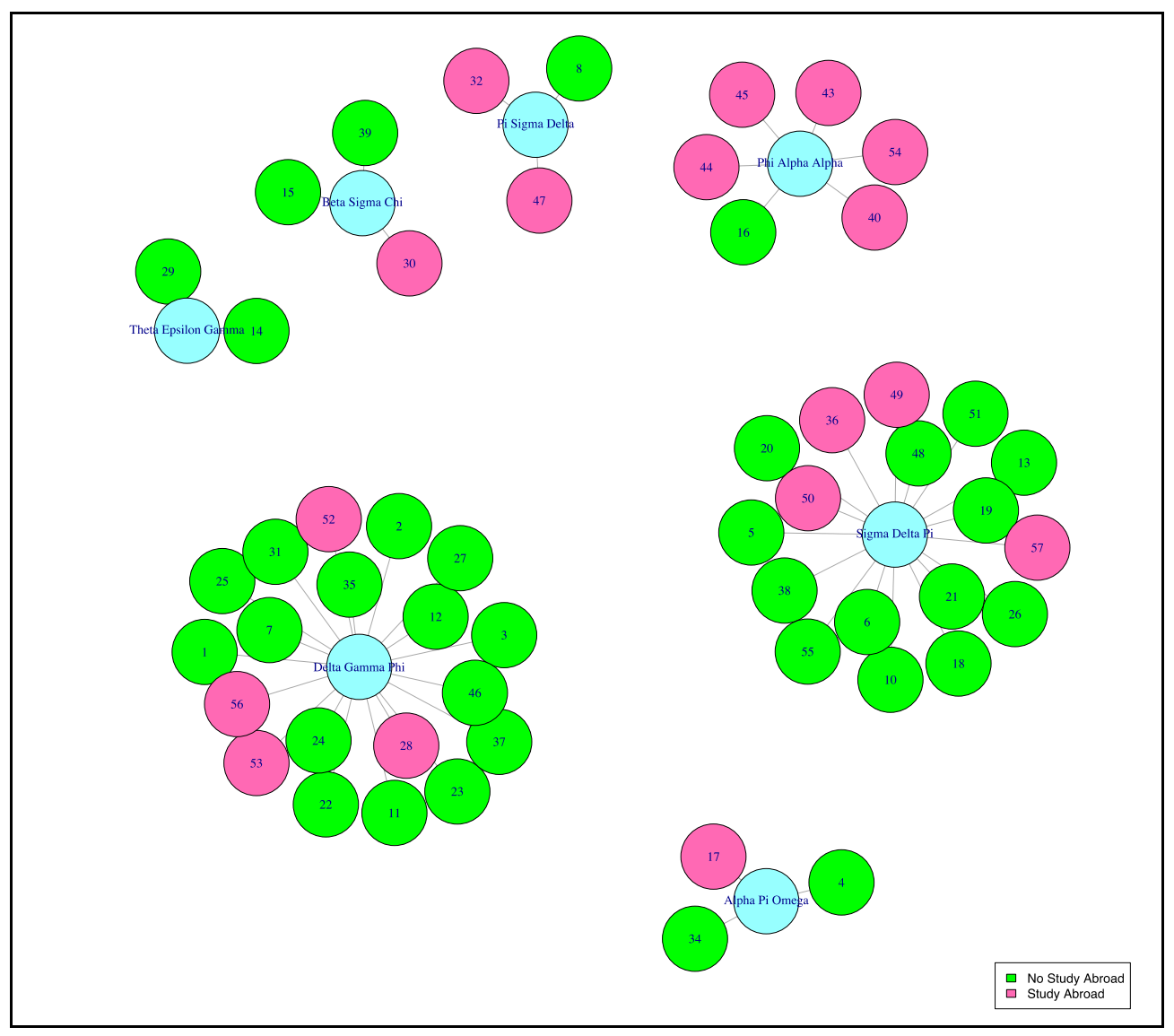

Table 1. Descriptive Statistics

\begin{tabular}{|c|c|c|c|c|}
\hline Variable & $\mathbf{N}$ & Mean & Min & Max \\
\hline Study Abroad Participation & 53 & 0.32 & 0 & 1 \\
\hline Study Abroad Intent & $36^{\mathrm{a}}$ & 0.61 & 0 & 1 \\
\hline Study Abroad Disposition & 53 & 0.74 & 0 & 1 \\
\hline Peer Effect & 53 & $0.46(0.37)^{\mathrm{b}}$ & 0 & 1 \\
\hline GPA & 53 & $3.59(0.33)^{\mathrm{b}}$ & 2.60 & 4.50 \\
\hline Female & 53 & 0.47 & 0 & 1 \\
\hline Previous Abroad Experience & 53 & 0.70 & 0 & 1 \\
\hline Major: STEM & 53 & 0.26 & 0 & 1 \\
\hline Major: Social Science & 53 & 0.21 & 0 & 1 \\
\hline Major: Business & 53 & 0.40 & 0 & 1 \\
\hline Major: Other & 53 & 0.13 & 0 & 1 \\
\hline
\end{tabular}

${ }^{a}$ Variable valid only for students who had not already participated in study abroad $(\mathrm{N}=36)$.

${ }^{\mathrm{b}}$ Standard deviation in parentheses. 


\section{Regression Models}

The results of the three regression models described previously are displayed in Table 2. For ease of interpretation, measures of peer effect were transformed from proportions to percentages (by multiplying each measure by 100) before inclusion in these models. As such, results for this independent variable are interpreted as the effect of a one percentage point increase in peer study abroad participation. Additionally, regression coefficients are displayed as marginal effects. For example, the coefficient for peer effect in the first column (Study Abroad Participation) indicates that with a one percentage point increase in the peer effect measure, the likelihood of a student having also participated in study abroad increases by almost 1 percent $(0.90)$. This result is significant at the $p<.05$ level. Similarly, a one percent point increase in peer effect is associated with a 1.5 percent increase in the likelihood of a student intending to participate in study abroad (Study Abroad Intent), although this result is not significant at any standard level. Finally, an increase of one percentage point in the peer effect measure resulted in a 0.60 percent increase in the likelihood that a student will have a positive disposition toward study abroad (Study Abroad Disposition). This result borders on significance $(\phi<.10)$.

Table 2. Regression Models for Study Abroad Participation (1), Study Abroad Intent (2), \& Study Abroad Disposition (3)

\begin{tabular}{llll}
\hline & $(1)$ & $(2)$ & $(3)$ \\
& Study Abroad Participation & Study Abroad Intent & Study Abroad Disposition \\
\hline Peer Effect & $0.009^{*}$ & 0.015 & $0.006+$ \\
& $(0.004)$ & $(0.010)$ & $(0.003)$ \\
GPA & -0.089 & 0.166 & 0.050 \\
& $(0.231)$ & $(0.325)$ & $(0.129)$ \\
Female (d) & 0.013 & & \\
& $(0.135)$ & -0.183 & -0.069 \\
& & $(0.244)$ & $(0.104)$ \\
Previous Abroad & $0.218+$ & & 0.147 \\
Experience (d) & $(0.121)$ & 0.305 & $(0.163)$ \\
& & $(0.254)$ & -0.247 \\
STEM (d) & 0.040 & & $(0.271)$ \\
& $(0.329)$ & -0.448 & \\
Business (d) & 0.141 & $(0.337)$ & $-0.289+$ \\
& $(0.322)$ & $-0.586+$ & $(0.252)$ \\
Social Science (d) & & $(0.282)$ & $-0.421+$ \\
& 0.159 & & $(0.328)$ \\
\hline Sample Size & $(0.463)$ & $-0.607+$ & 53 \\
Log Likelihood: Null & 53 & $(0.274)$ & -30.60 \\
Log Likelihood: Model & -33.25 & 36 & -19.85 \\
Chi-Square & -9.26 & -24.06 & 21.50 \\
Pseudo R & 47.99 & -19.71 & 0.35 \\
\hline Marinat & 0.72 & 8.69 & 0.18 \\
\end{tabular}

Marginal effects; Standard errors in parentheses

Reference categories are male (for gender) and Other (for major).

(d) for discrete change of dummy variable from 0 to 1

$+\mathrm{p}<.10, * \mathrm{p}<.05, * * \mathrm{p}<.01, * * * \mathrm{p}<.001$

\section{Limitations}

Prior to discussing the results of this study, it is important to note several of its limitations. This study, although the first to take on the analysis of peer influence on student study abroad patterns 
using network analysis tools, admittedly suffers from several limitations. The use of Greek organizations as a proxy for a student's peer group clearly ignores other sources of peer influence to which a student may be exposed while in college. As such, the analyses presented herein do not account for peer influence found in students' classes, among friends outside of their Greek life networks, or within their pre-college peer networks (e.g., high school friends). A similar limitation is that this study focuses on a group of students, those who belong to fraternities and sororities, who may be the most likely to participate in study abroad given their financial ability to pay for such an experience. Additionally, students participating in Greek life likely exhibit other characteristics, such as extraversion and participation in extensive alcohol use, that may link them to higher propensities for participation in study abroad (Park, Sher, Wood, \& Krull, 2009; Pedersen, LaBrie, Hummer, Larimer, \& Lee, 2010; Zimmermann \& Neyer, 2013). As such, results of this study are not necessarily generalizable to the entire undergraduate student population. Future research is needed to replicate this study using other definitions of student peer groups to address the limitations imposed by this study's use of Greek organizations to define who counts as a student's peer.

Another limitation of this study results from the survey nature of its data collection. Since completing this survey was optional for students, complete information was not collected for any of the Greek organizations represented. As such, measures of peer influence may be biased depending on which students chose to complete the survey. For example, in the hypothetical illustration presented in Figure 3, the peer influence measure for student 1 indicates that $50 \%$ of his or her peers studied abroad since one of his or her two peers who also completed the study's survey participated in a study abroad program. This peer measure may not be representative of student 1's true measure of study abroad peer influence if his or her peer with study abroad experience is only one of many in this Greek organization to study abroad. Similarly, given the voluntary nature of the survey, the number of students who chose to participate in this research is small, and may not be as representative of the population under investigation as would be desired. Additional limitations of this research include that information was not collected concerning the degree of interaction a student had with a specific peer or the valence of students' study abroad experiences. To this latter point, a peer whose study abroad experience was negative may have negatively influenced a student's thoughts and intentions concerning study abroad participation.

Despite these limitations, this study is valuable in that it contributes a more robust analysis of peer influence than otherwise available in the study abroad literature and provides a model for how peer influence may be measured in future research exploring student decision-making about study abroad.

\section{Discussion and Conclusion}

The results of this study point to some evidence for peer influence on students' study abroad decision-making, although not as much as one may expect given the results of at least one strand of previous research (Kasravi, 2009; Luo \& Jamieson-Drake, 2015; Salisbury et al., 2009; Zhai \& Scheer, 2002). Specifically, findings indicated no significant effect for peer influence on intent to study abroad (Research Question 2), but did indicate a significant effect for peer influence on study abroad participation (Research Question 1) and a marginally significant effect for peer influence on students' disposition toward study abroad (Research Question 3). For these latter two dependent variables, a percentage point increase in peer influence was associated with a slightly less than 1\% 
increase in their likelihood. These effects may be expected from the Theory of Planned Behavior that framed this study (Ajzen, 1988, 1991; Ajzen \& Fishbein, 1980, 2005; Fishbein \& Ajzen, 1975) since students' subjective norms surrounding study abroad (i.e., their peers' participation in education abroad experiences) significantly related to their own study abroad participation patterns and dispositions. Although beyond the scope of this investigation, it is quite possible that students' peers' experiences with study abroad also interacted with students' attitudes toward study abroad (attitude toward behavior) and their perceived ability to participate in study abroad (perceived behavioral control). Future research is needed to further explore how these components of the Theory of Planned Behavior may interact with one another.

The results of the current study contrast with those of prior research in regards to estimates of the magnitude of the effect of peer influence. That is, Zhai and Scheer (2002) found that 33\% of their participants were positively influenced by peers to study abroad, while the results of Kasravi (2009) indicated that $61.3 \%$ of participants mentioned former study abroad participants as influential in their own decisions to study abroad. These seemingly extreme differences in findings when comparing prior research with the current study likely stem from bias in the participant samples of prior research, which only inquired about reasons to participate in study abroad among students with study abroad experience. The current study's inclusion of students who had not studied abroad and were not interested in such an experience provides a more realistic picture of the U.S. undergraduate student population. As such, it is not surprising that the results just presented suggest that peers exerted a much smaller influence on students' study abroad decision-making than prior research would suggest. Additionally, the current study relied on an objective measure of peer influence on students' study abroad participation rather than on the self-reports of study abroad participants. It may be that participants in prior research indicated an influence of peers on their study abroad decisions because it was suggested in the data collection instruments used in these studies.

While the implications of, for example, a less-than-one-percent increase in the likelihood of a student participating in study abroad may not be particularly useful in practice, this study offers a first step toward a better understanding of peer influence on undergraduate student study abroad decision-making. Further and more extensive research is needed to unravel the complex relationship between a student's peers and his or her decisions about study abroad, including the decision not to participate. This area of inquiry would benefit from studies that are able to address some of the limitations of this study, for example by including a larger number of participants and peer groups beyond Greek organizations. These additional data may provide sufficient statistical power to detect a stronger significant effect for peer influence, or may continue to show that peer influence is not as strongly related to students' decisions about study abroad as prior research has suggested.

\section{Implications for Study Abroad Professionals}

This study offers additional food for thought on how peer influence may relate to student participation in study abroad that is particularly useful for study abroad professionals. First, it is worth considering that this study's findings are indicative of students joining organizations whose memberships are already representative of their own educational expectations, including those about study abroad. That is, students who enter college with positive inclinations towards study abroad participation may intentionally join organizations whose members value international experience. 
While the insignificance of the peer effect measure as it related to intent to study abroad attenuates this possibility to a degree (i.e., students do not seem to join Greek organizations based on the study abroad behaviors of its current members), this prospect warrants further examination. In this case, students' peers may not serve as the best way to reach student groups who are currently underrepresented in study abroad. Second, it may be that students' peers are more influential in other decisions about study abroad, such as where a student chooses to go or the type of program in which he or she participates, than in a student's initial decision to participate in study abroad. If this is, in fact, the case, study abroad professionals may need to evaluate the goals of study abroad programs to consider whether students are best served by study abroad through travel with groups comprised of their home-environment peers. It is possible that students are better off participating in study abroad programs if they are encouraged to expand their horizons and leave the comfort of their home peer group(s). A third possibility is that students' peers influence their decisions about study abroad indirectly, by influencing students' attitudes and opinions, which in turn influence their decisions about study abroad. This possibility was suggested previously in the context of the Theory of Planned Behavior and future research that might explore the interaction of its three constructs: attitude toward behavior, perceived behavioral control, and subjective norms. Such future research may be fruitful in uncovering the nuanced nature of peer influence on students' study abroad decision-making patterns. Clearly, the power of a student's peers in study abroad is certainly one that warrants future investigation.

\section{References}

100,000 Strong in the Americas. (2017). 100,000 Strong in the Americas. Retrieved from https://www.100kstrongamericas.org/

Ajzen, I. (1988). Attitudes, personality, and behavior. Chicago, IL: Open University Press.

Ajzen, I. (1991). The theory of planned behavior. Organizational Behavior and Human Decision Processes, 50, 179-211.

Ajzen, I., \& Fishbein, M. (1980). Understanding attitudes and predicting social behavior. London, England: Pearson.

Ajzen, I., \& Fishbein, M. (2005). The influence of attitudes on behavior. In D. Albarracin, B. T. Johnson, \& M. P. Zanna (Eds.), The handbook of attitudes (pp. 173-222). New York, NY: Lawrence Erlbaum.

Arbona, C., \& Nora, A. (2007). The influence of academic and environmental factors on Hispanic college degree attainment. The Review of Higher Education, 30(3), 247-269.

Astin, A. W. (1984). Student involvement: A developmental theory for higher education. Journal of College Student Personnel, 25(4), 297-308.

Borsari, B., \& Carey, K. B. (2001). Peer influences on college drinking: A review of the research. Journal of Substance Abuse, 13(4). 391-424.

Brux, J. M., \& Fry, B. (2010). Multicultural students in study abroad: Their interests, their issues, and their constraints. Journal of Studies in International Education, 14, 508-527.

Dessoff, A. (2006). Who's NOT going abroad? International Educator, 15(2), 20-27.

Doyle, S., Gendall, P., Meyer, L. H., Hoek, J., Tait, C., McKenzie, L., \& Loorparg, A. (2010). An investigation of factors associated with student participation in study abroad. Journal of Studies in International Education, 14, 471-490.

Engle, L., \& Engle, J. (2004). Assessing language acquisition and intercultural sensitivity development in relation to study abroad program design. Frontiers: The Interdisciplinary Journal of Study Abroad, 10, 219-236.

Fishbein, M., \& Ajzen, I. (1975). Attitude, intention and behavior: An introduction to theory and research. Reading, MA: Addison-Wesley. 
Fornerino, M., Jolibert, A., Sánchez, C. M., \& Zhang, M. (2011). Do values or goals better explain intent? A cross-national comparison. Journal of Business Research, 64, 490-496.

Freed, B. F. (Ed.). (1995). Second language acquisition in a study abroad context. Amsterdam, The Netherlands: John Benjamins.

Goel, L., de Jong, P., \& Schnusenberg, O. (2010). Toward a comprehensive framework of study abroad intentions and behaviors. Journal of Teaching in International Business, 21, 248-265.

Goldstein, S. B., \& Kim, R. I. (2006). Predictors of U.S. college students' participation in study abroad programs: A longitudinal study. International Journal of Intercultural Relations, 30, 507-521.

González Canché, M. S., \& Rios-Aguilar, C. (2015). Critical social network analysis in community colleges: Peer effects and credit attainment. New Directions for Institutional Research, 2014(163), 75-91.

Institute of International Education. (2017). Open Doors report on international educational exchange. Retrieved from http://www.iie.org/Research-and-Publications/Open-Doors

Kasravi, J. (2009). Factors influencing the decision to study abroad for students of color: Moving beyond the barriers (Unpublished doctoral dissertation). University of Minnesota, Minneapolis, MN.

Lo, S. (2006). Defining the peer advisor in the U.S. study abroad context. Journal of Studies in International Education, 10, 173-184.

Lokkesmoe, K. J., Kuchinke, K. P., \& Ardichvili, A. (2016). Developing cross-cultural awareness through foreign immersion programs: Implications of university study abroad research for global competency development. European Journal of Training and Development, 40, 166-170.

Luo, J., \& Jamieson-Drake, D. (2015). Predictors of study abroad intent, participation, and college outcomes. Research in Higher Education, 56, 29-56.

McCabe, D. L., Trevino, L. K., \& Butterfield, K. D. (2001). Cheating in academic institutions: A decade of research. Ethnics and Behavior, 11(3), 219-232.

McClure, K. R., Szelényi, K., Niehaus, E., Anderson, A. A., \& Reed, J. (2010). 'We just don't have that possibility yet': U.S. Latina/o narratives on study abroad. Journal of Student Affairs Research and Practice, 47, 363-382.

NAFSA. (2017). Senator Paul Simon study abroad program act. Retrieved from http://www.nafsa.org/Publicpolicy.aspx?id=6692

NCES. (2010). Classification of instructional programs. Retrieved fromhttps://nces.ed.gov/ipeds/cipcode/Default.aspx? $\mathrm{y}=55$

Niehaus, E. \& Inkelas, K. K. (2016). Understanding STEM majors' intent to study abroad. College Student Affairs Journal, 34, 70-84.

Park, A., Sher, K. J., Wood, P. K., \& Krull, J. L. (2009). Dual mechanisms underlying accentuation of risky drinking via fraternity/sorority affiliation: The role of personality, peer norms, and alcohol availability. Journal of Abnormal Psychology, 118(2), 241-255.

Pascarella, E. T. (1985). College environmental influences on learning and cognitive development: A critical review and synthesis. In J. C. Smart (Ed.), Higher education: Handbook of theory and research. New York, NY: Agathon.

Pedersen, E. R., LaBrie, J. W., Hummer, J. F., Larimer, M. E., \& Lee, C. M. (2010). Heavier drinking American college students may self-select into study abroad programs: An examination of sex and ethnic differences within a high-risk group. Addictive Behaviors, 35(9), 844-847.

Presley, A., Damron-Martinez, D., \& Zhang, L. (2010). A study of business student choice to study abroad: A test of the theory of planned behavior. Journal of Teaching in International Business, 21, 227-247.

Regan, V., Howard, M., \& Lemée, I. The acquisition of sociolinguistic competence in a study abroad context. Bristol, England: Multilingual Matters.

Salisbury, M. H., Paulsen, M. B., \& Pascarella, E. T. (2010). To see the world or stay at home: Applying an integrated student choice model to explore the gender gap in the intent to study abroad. Research in Higher Education, 51, 615-640. 
Salisbury, M. H., Paulsen, M. B., \& Pascarella, E. T. (2011). Why do all study abroad students look alike? Applying an integrated student choice model to explore differences in the factors that influence white and minority students' intent to study abroad. Research in Higher Education, 52, 123-150.

Salisbury, M. H., Umbach, P. D., Paulsen, M. B., \& Pascarella, E. T. (2009). Going global: Understanding the choice process of the intent to study abroad. Research in Higher Education, 50, 119-143.

Schnusenberg, O., de Jong, P., \& Goel, L. (2012). Predicting study abroad intentions based on the theory of planned behavior. Decision Sciences Journal of Innovative Education, 10, 337-361.

Stroud, A. H. (2010). Who plans (not) to study abroad? An examination of U.S. student intent. Journal of Studies in International Education, 14, 491-507.

Thomas, S. (2000). Ties that bind. The Journal of Higher Education, 71(3), 591-615.

Tinto, V. (1987). Leaving college: Rethinking the causes and cures of student attrition. Chicago, IL: University of Chicago Press.

Valente, T. W. (2005). Network models and methods for studying diffusion of innovations. In P. J. Carrington, J. Scott, \& S. Wasserman (Eds.), Models and methods in social network analysis (pp. 98116). Cambridge, England: Cambridge University Press.

Van Der Meid, J. S. (2003). Asian Americans: Factors influencing the decision to study abroad. Frontiers: The Interdisciplinary Journal of Study Abroad, 9, 71-110.

Whatley, M. (2017). Financing study abroad: An exploration of the influence of financial factors on student study abroad patterns. Journal of Studies in International Education, 21(5), 431-449.

Williams, F. (2007). Study abroad and Carnegie doctoral/research extensive universities: Preparing students from underrepresented racial groups to live in a global environment (Unpublished doctoral dissertation). Virginia Commonwealth University, Richmond, VA.

Williams, T. R. (2005). Exploring the impact of study abroad on students' intercultural communication skills: Adaptability and sensitivity. Journal of Studies in International Education, 9, 356-371.

Zhai, L. \& Scheer, S. D. (2002). Influence of international study abroad programs on agricultural college students. Journal of International Agricultural and Extension Education, 9(3), 23-29.

Zimmermann, J., \& Neyer, F. J. (2013). Do we become a different person when hitting the road? Personality development of sojourners. Journal of Personality and Social Psychology, 105(3), 515530. 


\section{Appendix A}

\section{Survey Subset}

\begin{tabular}{|c|c|}
\hline Survey Item & Response Categories (if applicable) \\
\hline $\begin{array}{l}\text { Are you a member of a sorority or a fraternity } \\
\text { here at (institution name)? }\end{array}$ & $\begin{array}{l}\text { Yes (if selected, students were presented with a } \\
\text { list of organizations to select their specific } \\
\text { fraternity or sorority) } \\
\text { No }\end{array}$ \\
\hline How old are you? & (fill in the blank) \\
\hline What is/are your major(s)? & (fill in the blank) \\
\hline $\begin{array}{l}\text { What is your current GPA? (If you are a first-year } \\
\text { student, please enter your final high school GPA.) }\end{array}$ & (fill in the blank) \\
\hline What is your gender? & (fill in the blank) \\
\hline What is your ethnicity? & $\begin{array}{l}\text { African American } \\
\text { American Indian } \\
\text { Asian } \\
\text { Hispanic } \\
\text { Multiracial } \\
\text { Pacific Islander } \\
\text { White/Caucasian } \\
\text { Other (please specify): } \\
\text { Prefer not to respond }\end{array}$ \\
\hline $\begin{array}{l}\text { Have you traveled abroad for non-study-abroad } \\
\text { purposes before (e.g., for vacation, a mission } \\
\text { trip)? }\end{array}$ & $\begin{array}{l}\text { Yes } \\
\text { No }\end{array}$ \\
\hline Have you studied abroad before? & $\begin{array}{l}\text { Yes } \\
\text { No (if selected, students were asked the following } \\
\text { question: } \\
\text { Do you plan to study abroad? } \\
\text { Yes } \\
\text { No) }\end{array}$ \\
\hline
\end{tabular}




\section{Appendix B}

\section{Peer Influence Calculations}

This appendix provides a detailed description of how peer influence was calculated in this study. First, a two-mode social network matrix was extracted from the dataset linking students (rows) to their Greek organization (columns), as shown in a simplified form in Figure B1. In this figure, a 1 appears in the column of the Greek organization of which a student was a member. Zero appears otherwise.

Figure B1. Two-mode network linking students (rows) to their Greek organization (columns)

$\left[\begin{array}{ccccc}\text { Student } & \text { Alpha Pi Omega } & \text { Beta Sigma Chi } & \text { Delta GammaPhi } & N \\ 1 & 1 & 0 & 0 & \ldots \\ 2 & 1 & 0 & 0 & \ldots \\ 3 & 1 & 0 & 0 & \ldots \\ 4 & 0 & 1 & 0 & \ldots \\ 5 & 0 & 1 & 0 & \ldots \\ 6 & 0 & 1 & 0 & \ldots \\ 7 & 0 & 0 & 1 & \ldots \\ 8 & 0 & 0 & 1 & \ldots \\ 9 & 0 & 0 & 1 & \ldots \\ 10 & 0 & 0 & 1 & \ldots \\ 11 & 0 & 0 & 1 & \ldots \\ N & \cdots & \cdots & \cdots & \cdots\end{array}\right]$

This matrix was then multiplied by its transpose to obtain a peer-to-peer relationship network based on Greek organization membership, as illustrated in Figure B2. In the resulting matrix, a 1 indicates that two students, represented by the student numbers at the heads of rows and columns, were members of the same Greek organization, while a 0 indicates that they were not members of the same organization. For example, the 1 in the second column of the first row indicates that students 1 and 2 were in the same Greek organization (Alpha Pi Omega). The 0 in the fourth column of the first row indicates that students 1 and 4 were not in the same organization (Alpha Pi Omega and Beta Sigma Chi, respectively). 
Figure B2. Peer-to-peer Greek organization network of students

$$
\left[\begin{array}{ccccccccccccc}
\text { Student } & 1 & 2 & 3 & 4 & 5 & 6 & 7 & 8 & 9 & 10 & 11 & N \\
1 & 1 & 1 & 1 & 0 & 0 & 0 & 0 & 0 & 0 & 0 & 0 & \cdots \\
2 & 1 & 1 & 1 & 0 & 0 & 0 & 0 & 0 & 0 & 0 & 0 & \cdots \\
3 & 1 & 1 & 1 & 0 & 0 & 0 & 0 & 0 & 0 & 0 & 0 & \cdots \\
4 & 0 & 0 & 0 & 1 & 1 & 1 & 0 & 0 & 0 & 0 & 0 & \cdots \\
5 & 0 & 0 & 0 & 1 & 1 & 1 & 0 & 0 & 0 & 0 & 0 & \cdots \\
6 & 0 & 0 & 0 & 1 & 1 & 1 & 0 & 0 & 0 & 0 & 0 & \cdots \\
7 & 0 & 0 & 0 & 0 & 0 & 0 & 1 & 1 & 1 & 1 & 1 & \cdots \\
8 & 0 & 0 & 0 & 0 & 0 & 0 & 1 & 1 & 1 & 1 & 1 & \cdots \\
9 & 0 & 0 & 0 & 0 & 0 & 0 & 1 & 1 & 1 & 1 & 1 & \cdots \\
10 & 0 & 0 & 0 & 0 & 0 & 0 & 1 & 1 & 1 & 1 & 1 & \cdots \\
11 & 0 & 0 & 0 & 0 & 0 & 0 & 1 & 1 & 1 & 1 & 1 & \cdots \\
N & \cdots & \cdots & \cdots & \cdots & \cdots & \cdots & \cdots & \cdots & \cdots & \cdots & \cdots & \cdots
\end{array}\right]
$$

So that a student was not selected as a member of his or her own peer group (i.e., so that a student's peer group consisted of all members of his or her Greek organization besides him or herself), the diagonal of the matrix shown in Figure B2 was converted to 0, as shown in Figure B3 (this figure corresponds to Figure 1 in this article's main text).

Figure B3. Peer-to-peer Greek organization network of students without self-selection

$$
\left[\begin{array}{ccccccccccccc}
\text { Student } & 1 & 2 & 3 & 4 & 5 & 6 & 7 & 8 & 9 & 10 & 11 & N \\
1 & 0 & 1 & 1 & 0 & 0 & 0 & 0 & 0 & 0 & 0 & 0 & \cdots \\
2 & 1 & 0 & 1 & 0 & 0 & 0 & 0 & 0 & 0 & 0 & 0 & \cdots \\
3 & 1 & 1 & 0 & 0 & 0 & 0 & 0 & 0 & 0 & 0 & 0 & \cdots \\
4 & 0 & 0 & 0 & 0 & 1 & 1 & 0 & 0 & 0 & 0 & 0 & \cdots \\
5 & 0 & 0 & 0 & 1 & 0 & 1 & 0 & 0 & 0 & 0 & 0 & \cdots \\
6 & 0 & 0 & 0 & 1 & 1 & 0 & 0 & 0 & 0 & 0 & 0 & \cdots \\
7 & 0 & 0 & 0 & 0 & 0 & 0 & 0 & 1 & 1 & 1 & 1 & \cdots \\
8 & 0 & 0 & 0 & 0 & 0 & 0 & 1 & 0 & 1 & 1 & 1 & \cdots \\
9 & 0 & 0 & 0 & 0 & 0 & 0 & 1 & 1 & 0 & 1 & 1 & \cdots \\
10 & 0 & 0 & 0 & 0 & 0 & 0 & 1 & 1 & 1 & 0 & 1 & \cdots \\
11 & 0 & 0 & 0 & 0 & 0 & 0 & 1 & 1 & 1 & 1 & 0 & \cdots \\
N & \cdots & \cdots & \cdots & \cdots & \cdots & \cdots & \cdots & \cdots & \cdots & \cdots & \cdots & \cdots
\end{array}\right]
$$

A list of all the dyadic relationships contained in the matrix exemplified in Figure B3 was then extracted, and study abroad participation was added as a characteristic of a given student's peer, as shown in Figure B4. For example, in Figure B4, student 2 is a peer of both students 1 and 3 as they belong to the same Greek organization (Alpha Pi Omega). Since student 2 studied abroad, a 1 appears in the rows of the third column (peerSA) representing the relationships between students 1 (student) and 2 (peer) and students 3 (student) and 2 (peer). Similarly, since student 3 did not study abroad, a 0 appears in the peerSA column for all the students of which student 3 is a peer. 
Melissa Whatley

Figure B4. Peer study abroad participation

$\left[\begin{array}{ccc}\text { Student } & \text { Peer } & \text { peerSA } \\ 1 & 2 & 1 \\ 1 & 3 & 0 \\ 2 & 1 & 0 \\ 2 & 3 & 0 \\ 3 & 1 & 0 \\ 3 & 2 & 1 \\ 4 & 5 & 1 \\ 4 & 6 & 0 \\ 5 & 4 & 0 \\ 5 & 6 & 0 \\ 6 & 4 & 0 \\ 6 & 5 & 1 \\ N & \cdots & \cdots\end{array}\right]$

A peer-to-peer study abroad matrix was then extracted from this list of students, their peers, and peers' study abroad participation. In this matrix, row entries represent a peer's participation in study abroad status, as illustrated in Figure B5 (this figure corresponds to Figure 2 in this article's main text). Specifically, a 1 appears in a column for a given student's row if two conditions are met: 1) the student represented in the column belonged to the same Greek organization as the row student (i.e., was a peer of the student) and 2) the student represented in the column participated in study abroad. For example, student 2 is both a peer of student 1 and studied abroad. These relationships are captured by a 1 in the first row (student 1) of the second column (student 2). Note that the diagonal of this matrix, like that of the matrix of the peer-topeer network based on Greek organization in Figure B3, is set equal to 0 so that a student is not counted among his or her study abroad peer group.

Figure B5. Peer-to-peer study abroad network

$$
\left[\begin{array}{ccccccccccccc}
\text { Student } & 1 & 2 & 3 & 4 & 5 & 6 & 7 & 8 & 9 & 10 & 11 & N \\
1 & 0 & 1 & 0 & 0 & 0 & 0 & 0 & 0 & 0 & 0 & 0 & \cdots \\
2 & 0 & 0 & 0 & 0 & 0 & 0 & 0 & 0 & 0 & 0 & 0 & \cdots \\
3 & 0 & 1 & 0 & 0 & 0 & 0 & 0 & 0 & 0 & 0 & 0 & \cdots \\
4 & 0 & 0 & 0 & 0 & 1 & 0 & 0 & 0 & 0 & 0 & 0 & \cdots \\
5 & 0 & 0 & 0 & 0 & 0 & 0 & 0 & 0 & 0 & 0 & 0 & \cdots \\
6 & 0 & 0 & 0 & 0 & 1 & 0 & 0 & 0 & 0 & 0 & 0 & \cdots \\
7 & 0 & 0 & 0 & 0 & 0 & 0 & 0 & 0 & 0 & 0 & 0 & \cdots \\
8 & 0 & 0 & 0 & 0 & 0 & 0 & 0 & 0 & 0 & 0 & 0 & \cdots \\
9 & 0 & 0 & 0 & 0 & 0 & 0 & 0 & 0 & 0 & 0 & 0 & \cdots \\
10 & 0 & 0 & 0 & 0 & 0 & 0 & 0 & 0 & 0 & 0 & 0 & \cdots \\
11 & 0 & 0 & 0 & 0 & 0 & 0 & 0 & 0 & 0 & 0 & 0 & \cdots \\
N & \cdots & \cdots & \cdots & \cdots & \cdots & \cdots & \cdots & \cdots & \cdots & \cdots & \cdots & \cdots
\end{array}\right]
$$

The peer-to-peer networks represented in Figures B3 (Greek organization) and B5 (peer study abroad) (corresponding to Figures 1 and 2, respectively, in this article's main text) were 
subsequently used to calculate the measure of personal network exposure to study abroad. Specifically, row sums for both matrices were calculated for each student. The row sums resulting from the peer-to-peer Greek organization matrix in Figure B3 calculated the number of peers a student had in his or her Greek organization while the row sums resulting from the peerto-peer study abroad matrix in Figure B5 calculated the number of peers with study abroad experience. The proportion of a student's peers with study abroad experience was then calculated by dividing the number of peers with study abroad experience by the total number of peers for each student. Figure B6 (which corresponds to Figure 3 in this article's main text) provides examples of how these measures were calculated for students in two example Greek organizations, Alpha Pi Omega (students 1-3) and Beta Sigma Chi (students 4-6).

Figure B6. Peer influence measures

$\left[\begin{array}{cccc}\text { Student } & \text { \#peersSA } & \text { \#peers } & \text { \#peersSA } \\\right.$\cline { 3 - 4 } 1 & 1 & 2 & \text {$\left.\#peers } \\ 2 & 0 & 2 & 0.5 \\ 3 & 1 & 2 & 0.5 \\ 4 & 1 & 2 & 0.5 \\ 5 & 0 & 2 & 0 \\ 6 & 1 & 2 & 0.5 \\ N & \cdots & \cdots & \cdots / \cdots\end{array}\right]$

